\title{
Dukungan Lingkungan Sosial Budaya terhadap Kemampuan Petani dalam Pengelolaan Hutan Kemiri di Kabupaten Maros Provinsi Sulawesi Selatan
}

\author{
(The contribution of Cultural Social Environment to Farmers' Ability in Managing \\ Candlenut Forest in Maros District, South Sulawesi Province)
}

\author{
Adi Riyanto Suprayitno ${ }^{1}$, Sumardjo ${ }^{2}$, Darwis S Gani ${ }^{2}$, dan Basita G. Sugihen ${ }^{2}$ \\ ${ }^{1}$ Balai Pendidikan dan Pelatihan Kehutanan Makassar \\ ${ }^{2}$ Departemen Sains Kominikasi dan Pengembangan Masyarakat \\ Fakultas Ekologi Manusia Institut Pertanian Bogor
}

\begin{abstract}
Farmers living around the candlenut forest in Maros District have been managing and utilizing candlenut forest since 1826. These activities have been part of their daily living activities. The existence of candlenut forest is a successful evidence of farmers ability in managing that forest. It is presumed that the cultural social environtment has important roles to form the farmers' ability to manage and to utilize candlenut forest. The research intended to analyze the contribution of cultural social environment to farmers' ability in managing and utilizing candlenut forest. The data were collected on January-Maret 2010 in Maros District, South Sulawesi Province using some methods: questionnare list, interview, observation, and documents. The data were analyzed using (1) descriptive statistics, and (2) inferensial statistics based on SEM using LISREL 8.70 software programming. The result shows that farmers' contribution of cultural social environment, today is low. It, however, has a positive contribution for increasing farmers' ablity.
\end{abstract}

Key words: Cultural social environment, farmers ability, community candlenut forest

\section{Abstrak}

Petani sekitar hutan kemiri di Kabupaten Maros telah mengelola dan memanfaatkan hutan kemiri sejak tahun 1826. Kegiatan tersebut telah menjadi bagian dari aktivitas petani sehari-hari. Keberadaan hutan kemiri, saat ini, merupakan bukti kesuksesan atas kemampuan petani dalam mengelola hutan kemiri. Lingkungan sosial budaya diduga memiliki peran penting dalam membentuk kemampuan petani dalam mengelola dan memanfaatkan hutan kemiri. Penelitian bertujuan untuk menganalisa kontribusi lingkungan sosial budaya terhadap kemampuan petani dalam mengelola dan memanfaatkan hutan kemiri. Pengumpulan data dilaksanakan pada Januari- Maret 2010 melalui angket, wawancara, observasi, dan studi dokumen. Analisis data menggunakan (1) statistik deskriptif, dan (2) statistik inferensial memakai SEM dengan bantuan program LISREL 8.70. Penelitian menyimpulkan bahwa walaupun, pada saat ini dukungan lingkungan sosial budaya tergolong rendah, namun memiliki kontribusi positip terhadap peningkatan kemampuan petani.

Kata Kunci: Lingkungan sosial budaya, kemampuan petani, hutan kemiri rakyat

\section{Pendahuluan}

Hutan sebagai anugerah dan karunia Tuhan Yang Maha Esa merupakan kekayaan yang sangat banyak manfaatnya bagi kelangsungan seluruh makhluk hidup. Hutan memiliki fungsi sebagai penyangga kehidupan, karena hutan mengandung fungsi yang amat dibutuhkan untuk kemanfaatan dan kelangsungan kehidupan. Fungsi tersebut akan musnah bila secara fisik hutan mengalami kerusakan. Oleh karena itu, pemanfaatan dan pemanfaatan hutan harus mengedepankan kelestariannya.

\footnotetext{
${ }^{1}$ Korespondensi, Telepon: 08128760883

e-mail: adiriyantosuprayitno68@yahoo.com
}

Hutan dan petani yang tinggal di sekitarnya berada pada tataran hubungan yang sangat interaktif. Petani sekitar hutan kemiri Kabupaten Maros telah melakukan mengelola hutan kemiri sejak lama secara turun temurun untuk dimanfaatkan buahnya. Pengelolaan dan pemanfaatan hutan kemiri telah menjadi bagian dari aktivitas kehidupan sehari-hari petani sekitar hutan. Petani sekitar hutan mempunyai cara tersendiri dalam mengelola hutan kemiri dan telah menjadi bagian dari sistem sosial budaya mereka. Mereka memandang hutan kemiri tidak sebagai hutan melainkan sebagai kebun. Kata hutan berasal dari luar petani yang melihat tampilan tegakan 
kemiri hasil budidaya petani serupa dengan definisi dan karakteristik hutan. Hutan kemiri menjadi salah satu sumber pendapatan tetap dan sebagai faktor pengaman ekonomi rumah tangga petani.

Pengelolaan dan pemanfaatan hutan kemiri tidak dapat berlangsung sebagaimana yang diharapkan apabila para petani tidak memiliki kemampuan yang memadai. Kepemilikan kemampuan akan membedakan kinerja petani dalam mengelola hutan kemiri, artinya akan terlihat antara petani yang mampu mengelola hutan secara baik dengan petani yang belum mampu mengelola hutan secara baik. Keberadaan kebun kemiri yang saat ini tampilannya mirip dengan hutan merupakan bukti bahwa petani sekitar hutan memiliki kemampuan yang memadai dalam mengelola dan memanfaatkan hutan kemiri. Namun demikian, sejak diberlakukannya Tata Guna Hutan Kesepakatan (TGHK) pada tahun 1984, petani sekitar hutan mengalami keterbatasan akses terhadap hutan kemiri yang telah lama dikelolanya. Hal ini mengakibatkan aktivitas petani dalam mengelola hutan kemiri menjadi dibatasi. Pembatasan ini dapat memperlemah kemampuan petani dalam mengelola hutan kemiri.

Kemampuan merupakan potensi diri yang dapat dikembangkan (Klausmeier dan Goodwin, 1975). Peningkatan dan pengembangan kemampuan dapat terjadi melalui proses proses belajar. Menurut teori belajar aliran behavioral (Seng, 2001), bahwa proses belajar dalam diri seseorang pada umumnya dipengaruhi oleh berbagai faktor salah satunya adalah faktor eksternal.

Lingkungan sosial budaya merupakan faktor eksternal yang dapat mempengaruhi kemampuan petani dalam pengelolaan hutan kemiri sebagaimana dikemukakan oleh Delgado (Rakhmat, 2002) bahwa respons otak dan perilaku individu dipengaruhi oleh setting atau suasana yang melingkupi individu tersebut, demikian pula Sarwono (2002) menyatakan bahwa individu akan merespons stimulus yang datang dari lingkungan dengan cara-cara tertentu. Santosa (2004) dalam penelitiannya menyimpulkan bahwa lingkungan sosial memiliki pengaruh besar terhadap perilaku adaptif petani tepian hutan. Hal ini berarti, lingkungan sistem sosial budaya yang di dalamnya terdapat interaksi antara petani dengan petani, petani dengan pihak luar petani, dan petani dengan alam sekitarnya, disadari atau tidak disadari, dapat membentuk kemampuan petani dalam mengelola hutan kemiri.

Nilai, norma dan aturan yang berlaku dalam lingkungan sosial budaya telah membentuk kemampuan dan mengatur perilaku petani dalam mengelola hutan kemiri sehingga tercipta harmonisasi atau keseimbangan kepentingan antara petani dengan petani dan petani dengan hutan kemiri. Kemampuan petani sekitar hutan dalam mengelola dan memanfaatkan hutan kemiri lahir dari kebutuhan bersama di antara petani untuk mengantisipasi dan menghadapi masalah dan tantangan hidup dan meraih peluang yang ada di sekitar mereka. Oleh karena itu perlu kiranya menjaga sistem sosial budaya dan mempertahankan serta mengembangkan kemampuan petani sekitar hutan kemiri dalam mengelola hutan kemiri sehingga pengelolaan hutan kemiri dapat berjalan dengan baik dan keberadaan hutan kemiri dapat terjaga kelestariannya. Berdasarkan hal tersebut dirumuskan masalah penelitian yaitu sejauhmana lingkungan sosial budaya memberikan pengaruh pada tingkat kemampuan petani sekitar hutan dalam mengelola hutan kemiri. Tujuan penelitian ini adalah: menganalisis dukungan lingkungan sosial budaya terhadap kemampuan petani sekitar hutan kemiri dalam pengelolaan hutan kemiri.

\section{Metode Penelitian}

Desain penelitian yang digunakan adalah ex post facto. Desain penelitian ex post facto digunakan untuk menjajagi kemungkinan hubungan kausalitas (sebab-akibat) di antara variabel bebas dan variabel terikat tanpa adanya manipulasi atau perlakuan dari peneliti terhadap variabel terikat (Kountor, 2006; Hadjar, 1996; Sevilla et.al., 1993). Lokasi penelitian adalah desa-desa yang berada di sekitar hutan kemiri kawasan pegunungan Bulusaraung di tiga kecamatan di kabupaten Maros Provinsi Sulawesi Selatan. Pemilihan lokasi dilakukan secara purposive 
Jurnal $\mathcal{P}$ enyuluhan, Maret 2012 Vol. 8 No. 1

dengan pertimbangan bahwa hutan kemiri kawasan pegunungan Bulusaraung merupakan areal hutan kemiri terluas di Sulawesi Selatan. Populasi penelitian adalah kepala keluarga/rumah tangga petani yang lahan dan/atau menggarap hutan kemiri dengan jumlah 10.091 jiwa. Jumlah sampel penelitian sebanyak 204 kepala rumah tangga (berdasarkan rumus rumus slovin dengan presisi $8 \%$ diperoleh jumlah sampel 154 kepala keluarga). Pemilihan sampel dilakukan secara acak proporsional (proporsionate random sampling). Pengumpulan data primer dilakukan dengan cara pengisisan kuesioner, wawancara dan observasi langsung. Data sekunder diperoleh dari berbagai kantor/instansi terkait. Pengolahan dan analisa data menggunakan (1) statistik deskriptif, dan (2) statistik inferensial (SEM dengan menggunakan software LISREL 8.70).

Tabel 1. Sebaran Rataan Skor Dukungan Lingkungan Sosial Budaya
Hasil dan Pembahasan

\section{Gambaran Singkat Lokasi Penelitian}

Kawasan hutan kemiri pegunungan Bulusaraung di Kabupaten Maros secara administrasi pemerintahan terletak di Kecamatan Cenrana, Kecamatan Camba, dan Kecamatan Malawa. Luas wilayah ketiga kecamatan tersebut adalah 56,616 $\mathrm{Ha}$, yang secara geografis terletak pada $4^{0} 45^{\prime} 52^{\prime}$, -

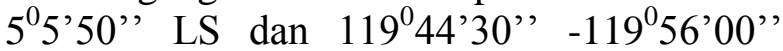
BT. Persentase luas wilayah Kecamatan Cenrana terhadap keseluruhan luas Kabupaten Maros adalah $11 \%$, Kecamatan Camba adalah 9\% dan Kecamatan Malllawa sebesar $14 \%$.

Menurut Dinas Kehutanan dan Perkebunan Maros (2009), total luas hutan kemiri dari ketiga wilayah kecamatan tersebut adalah $9.341 \mathrm{Ha}$, dengan ketinggian dari permukaan laut 300 - 1.200 meter, dimana Kecamatan Mallawa adalah yang terluas hutan kemirinya yaitu $5.056 \mathrm{Ha}$, sedangkan Kecamatan Cenrana adalah $2.070 \mathrm{Ha}$ dan Kecamatan Camba seluas 2.215 Ha.

\begin{tabular}{l|c|c|c|c}
\hline \multirow{2}{*}{ Dukungan Lingkungan Sosial Budaya } & Kec. Cenrana & Kec. Camba & Kec. Mallawa & Total \\
\cline { 2 - 5 } & $\%$ & $\%$ & $\%$ & $\%$ \\
\hline Dukungan Kearifan Lokal & & & & \\
Rendah & 46,3 & 40 & 49 & 46,1 \\
Sedang & 18,5 & 34 & 39 & 32,3 \\
Tinggi & 35,2 & 26 & 12 & 21,6 \\
\hline Rataaan skor & 56,2 & 59 & 56,5 & 57 \\
\hline Dukungan Tokoh Masyarakat & & & & \\
Rendah & 70,4 & 94 & 91 & 86,3 \\
Sedang & 29,6 & 6 & 9 & 13,7 \\
Tinggi & 0 & 0 & 0 & 0 \\
\hline Rataaan skor & $36,4^{(\mathrm{a})}$ & $29,7^{(\mathrm{a})}$ & 33,1 & 33,1 \\
\hline Dukungan kelompok tani & 92,6 & 100 & 99 & 97,5 \\
Rendah & 7,4 & 0 & 1 & 2,5 \\
Sedang & 0 & 0 & 0 & 0 \\
Tinggi & $18,1^{(\mathrm{a})}$ & $24^{(\mathrm{a})}$ & 15,2 & 18,1 \\
\hline Rataaan skor & & & &
\end{tabular}

Sumber: Analisis Data Primer, 2010

Keterangan: $\sum$ Cenrana $=54 ; \sum$ Camba $=50 ; \sum$ Mallawa $=100$

(a); hasil uji beda dengan ANAVA pada $\alpha=5 \%$

Kategori; Rendah $=$ skor $0-50$, Sedang $=$ skor $51-75$, Tinggi $=$ skor $76-100$ 
Keadaan topografi secara makro bervariasi mulai dari datar/landai sampai dengan bergunung. Sebagian besar (58\%) wilayah tersebut memiliki kelerengan curam, sedangkan hanya $28,1 \%$ yang memiliki kelas lereng landai sampai dengan bergelombang. Batas-batas wilayah administrasi kawasan hutan kemiri adalah di sebelah utara dan timur berbatasan dengan Kabupaten Bone, di sebelah barat berbatasan dengan Kecamatan Bantimurung, dan di sebelah selatan berbatasan dengan Kecamatan Tompobulu.

\section{Kondisi Dukungan Lingkungan Sosial Budaya}

Lingkungan sosial, budaya dan alam memiliki pengaruh terhadap perilaku manusia (Soemarwoto, 1999; Sarwono, 2002; Santosa, 2004). Ndraha (1999) mengemukakan bahwa terdapat hubungan transaksi antara manusia dengan lingkungannya baik lingkungan sosial maupun lingkungan alam. Manusia hidupnya bergantung pada dan dipengaruhi oleh lingkungan, demikian pula kontribusi dan perilakuan manusia kepada lingkungan akan memberikan nilai atau manfaat kepada lingkungan tersebut.

Dukungan lingkungan sosial budaya terhadap kemampuan petani sekitar hutan dalam pengelolaan hutan kemiri, pada saat ini, secara umum dapat dikatakan tergolong rendah, terlihat dari rendahnya aspek dukungan tokoh masyarakat maupun dukungan kelompok tani, kecuali aspek dukungan kearifan lokal yang tergolong sedang (Tabel 1).

\section{Dukungan Kearifan Lokal}

Praktek pengelolaan hutan kemiri yang dilakukan petani sekitar hutan kemiri Kabupaten Maros merupakan bentuk kearifan lokal karena dilandasi oleh pengetahuan, nilai dan norma kearifan yang berlaku dalam sistem budaya setempat dan telah berlaku secara turun temurun. Pada saat ini, dukungan kearifan lokal dalam pengelolaan hutan kemiri di kabupaten Maros pada umumnya berada dalam kategori sedang, yang ditandai dengan rataan skor total sebesar 57. Terlihat (Tabel 1) bahwa sebagian besar responden $(63,9 \%)$ memiliki persepsi yang cenderung tinggi terhadap dukungan kearifan lokal yaitu 32,3\% rerponden menyatakan sedang dan 21,6 responden menyatakan tinggi.

Secara statistik tidak terdapat perbedaan nyata dukungan kearifan lokal di antara tiga kecamatan tersebut. Hal ini berarti, kearifan lokal tersebut cukup mampu memberikan dukungan bagi pengelolaan hutan kemiri secara lestari pada tiga kecamatan tersebut, walaupun pada kenyataannya telah terjadi sedikit pergeseran atau kelunturan kekuatan, keterikatan dan penghayatan terhadap nilai kearifan lokal tersebut sebagai akibat diberlakukannya TGHK.

Praktek pengelolaan hutan kemiri di Kabupaten Maros dalam bentuk kebun hutan sudah lama dikembangkan penduduk dalam bentuk dare' ampiri (kebun kemiri). Pengelolaan hutan kemiri Kabupaten Maros yang dilakukan petani sekitar hutan memiliki cara tersendiri dan menjadi bagian dari sistem budaya mereka. Hutan merupakan bagian yang tidak terpisahkan dengan alam dirinya, sehingga untuk menjaga keseimbangan ekosistem di dalamnya terdapat aturan-aturan atau norma-norma tersendiri yang harus dipatuhi oleh semua petani. Aturan-aturan atau norma-norma tersebut merupakan kearifan lokal yang telah melembaga dan menjadi etos kerja dan menjadi sistem pengetahuan pengelolaan hutan bagi petani sekitar hutan kemiri. Mitchell et.al. (2007) mengemukakan bahwa sistem pengetahuan lokal sangat ampuh dan memiliki peran sangat besar sepanjang sejarah hidup manusia dalam menjaga keseimbangan lingkungan alam.

Petani sekitar hutan kemiri kemiri Kabupaten Maros memiliki sistem nilai, pengetahuan, teknologi dan sistem kelembagaan dalam mengelola hutan kemiri. Meskipun tradisional namun mengandung kearifan dalam mengelola dan memanfaatkan hutan kemiri. Kearifan dalam pemanfaatan hutan telah melembaga dan menjadi institusi lokal yang termanifestasi dalam praktek pengelolaan hutan kemiri yang meliputi kegiatan mappamula/makkoko, madare, makampiri dan maddepa. Di setiap kegiatan tersebut berbagai norma, nilai dan aturan yang 
Jurnal $\mathcal{P}$ enyuluhan, Maret 2012 Vol. 8 No. 1

merupakan unsur kearifan lokal dijadikan landasan sehingga menciptakan hubungan yang serasi antara petani dengan hutan kemiri, dan telah menciptakan hubungan yang harmonis di antara petani dalam pengelolaan hutan kemiri. Hasil budidaya dan pengelolaan tanaman kemiri yang dilakukan petani memperlihatkan tampilan yang menyerupai hutan tidak hanya menjadi sumber penghasilan bagi petani, tetapi juga menjamin kelestarian lingkungan secara berkelanjutan.

\section{Mappamula}

Mappammula/makkoko adalah kegiatan untuk mempersiapkan lahan. Kegiatan ini disertai upacara atau ritual tertentu, dipimpin oleh orang yang dituakan atau sanro (dukun) yang dilaksanakan pada akhir musim kemarau yaitu bulan September dan Oktober yang meliputi penentuan lokasi, pembukaan lahan, pembersihan lokasi, pengadaan bibit dan pengolahan tanah. Dalam penentuan lokasi, petani memilih lokasi/lahan yang tidak jauh dari tempat tinggalnya dengan topografi datar yang memungkinkan tanaman kemiri dapat tumbuh dengan baik, dengan empat macam pilihan lokasi, yaitu lebba (berada di antara gunung), empe (lokasi/lahan miring atau pinggiran gunung), lappa (lokasi terbuka, datar jauh dari gunung), dan garoppo (lahan yang berbatu). Pada umumnya para petani memilih lahan lebba. Lahan lappa biasanya digunakan petani untuk bercocoktanam tanaman semusim.

Mappammula/ makkoko diawali dengan menetapkan batas lahan yang akan dibuka, setelah itu dilakukan kegiatan membersihkan tumbuhan bawah tegakan yaitu membabat semak dan alang-alang, selanjutnya menebang pohon-pohon yang besar. Kegiatan selanjutnya adalah pembakaran (mattunu) di atas areal yang telah dibersihan dengan maksud agar tanah menjadi panas sehingga benih tanaman mudah berkecambah. Kegiatan pembukaan lahan ini dikerjakan oleh pemilik lahan atau dipercayaan kepada pakkoko/paddare yaitu orang yang berkebun pada lahan milik orang lain dengan kesepakatan tertentu dengan pemiliknya. Setelah itu dilakukan pembersihan lahan dari sisa-sisa pembakaran dan penggemburan untuk persiapan penanaman (maddare).

\section{Pengadaan Bibit}

Pengadaan bibit dilakukan dengan dua cara yaitu pengadaan benih atau pemilihan biji, dan mengambil anakan alami kemiri. Pengadaan benih atau biji dilakukan dengan cara memilih pohon induk sebagai sumber benih dengan kriteria masih produktif setiap tahun dan berbuah lebat, usia 15-25 tahun, memiliki batang yang besar dan tajuk yang yang lebar. Buah yang berkualitas baik untuk benih dicirikan dengan isinya yang utuh tidak pecah pada saat dikupas dan berasal dari buah kemiri yang memiliki biji kembar dua (kabba). Petani mengidentifikasikan biji kemiri dengan istilah jantan dan betina. Biji betina bentuknya gepeng (pipih) dan dipangkalnya ada lekukan, sedangkan yang bentuknya bulat adalah biji jantan. Menurut petani, biji betina lebih mudah dan cepat tumbuh dibandingkan dengan biji jantan. Biji betina pada umumnya dihasilkan dari buah yang berbiji kembar. Pengambilan benih/biji dilakukan pada bulan November yakni pada akhir musim berbuah atau sekitar tiga bulan sebelum penanaman, kemudian dikeringkan selama satu hari (dijemur), setelah itu disimpan sampai pada waktu penanaman.

Pengambilan anakan alami sebagai bibit dilakukan dengan memperhatikan induk pohon kemiri di atasnya yaitu pohon kemiri yang pertumbuhannya baik, batang tegak, sehat, tidak terserang hama/penyakit dan berbuah lebat. Pengambilan anakan alami dilakukan dengan sistem cabutan.

\section{Maddare}

Maddare adalah kegiatan penanaman kemiri yang dilakukan secara langsung di lapangan dengan menggunakan biji (tanpa melalui kegiatan persemaian), dengan pertimbangan bahwa biaya lebih murah dan pelaksanaannya lebih mudah jika dibandingkan penanaman dengan menggunakan bibit. Penanaman dilakukan dengan dua cara yaitu penanaman sebelum dan setelah pembakaran. Penanaman sebelum pembakaran dilaksanakan dengan cara menanam biji ke dalam lubang sedalam $5-10 \mathrm{~cm}$ kemudian ditutup 
kembali, setelah itu di atas tanah tersebut dilakukan pembakaran kayu, daun kering, ranting sisa pembersihan. Sedangkan penanaman setelah pembakaran dilakukan dengan cara menanam biji ke dalam lubang sedalam 2-3 $\mathrm{cm}$ atau sedikit bagian dari biji tersebut terlihat menonjol ke permukaan tanah pada lahan yang telah mengalami pembakaran dan telah bersih. Menurut petani penanaman sebelum embakaran memiliki tingkat perkecambahan yang lebih tinggi dibandingan dengan setelah pembakaran. Kegiatan penanaman biasanya dilakukan pada awal musim hujan, selanjutnya seraya menunggu tanaman kemiri besar dan berbuah serta tajuk lebat menutupi lahan, dilakukan penanaman tanaman semusim seperti kacang tanah, jagng dan sayur-sayuran selama 2-3 tahun.

\section{Pemeliharaan}

Pemeliharaan tanaman kemiri pada umumnya dilakukan hanya pada saat panen (sekali dalam setahun), dengan melakukan penebasan atau pembersihan tanaman pengganggu untuk memudahkan memungut buah kemiri. Pemeliharaan berkala biasanya dilakukan petani pada waktu tertentu saja seperti saat berbunga atau pada saat mulai berbuah. Pemeliharaan rutin biasanya dilakukan oleh petani yang memiliki lahan relatif datar dimana biasanya di bawah tegakan kemiri dilakukan tumpang sari tanaman cokelat.

Pemeliharaan tanaman kemiri sejak ditanam sampai dengan berbuah (usia 0-3 tahun) biasanya dilakukan oleh pakokko karena sambil menunggu tanaman kemiri mulai berbuah oleh pakokko lahan tersebut dimanfaatkan dengan menanam tanaman semusim

\section{Makkampiri}

Makkampiri adalah kegiatan pemanenan yang dilakukan bertepatan dengan awal musim hujan yaitu bulan Nopember atau Desember. Pemanenan dilakukan dengan cara memungut buah kemiri yang jatuh ke permukaan tanah. Hal ini dilakukan selain karena faktor ketinggian pohon juga karena buah kemiri yang jatuh ke atas tanah menurut petani memiliki kualitas yang baik. Cara pemungutan buah kemiri terdiri atas pemungutan yang dilakukan pada saat kulit luar buah kemiri terpisah dengan kulit dalam (makkacone) dan pemungutan sebelum terpisah antara kulit luar buah kemiri dengan kulit dalamnya (makkaba). Petani lebih suka melakukan pemungutan makkacone karena mudah pelaksanaannya dan juga mudah membedakan buah kemiri yang hampa dengan yang berisi. Sedangkan pemungutan makkaba dirasakan lebih sulit karena kemiri masih kotor, dan sulit membedakan antara kemiri yang hampa dengan yang berisi.

Pemanenan dilakukan secara bertahap yaitu panen raya (makkampiri), panen susulan (mabbali), dan panen akhir (makkalice). Makkampiri dilakukan oleh pemilik lahan atau orang yang dipekerjakan oleh pemilik lahan dengan memungut buah kemiri dengan kategori makkacone. Mabbali dilakukan oleh pemilik lahan atau orang lain yang dipekerjakan oleh pemilik lahan dengan memungut sisa buah kemiri yang belum jatuh pada saat makkampiri. Ketika tanaman kemiri sudah berbuah dan terlihat banyak, oleh petani pemilik lahan dengan bantuan dukun kampung (sanro), dipasang hompong (tanda larangan yang telah diberi mantera). Hompong adalah daun enau atau kain kafan/puitih (kaci) yang dipasang atau digantung pada batang kemiri dan akan dicabut setelah berakhirnya mabbali.

Pemasangan hompong dimaksudkan sebagai peringatan kepada orang lain untuk tidak melakukan pemungutan buah kemiri pada lahan tersebut tanpa seizin pemiliknya, dengan kata lain untuk menghindari pencurian. Selain itu, hompong berfungsi untuk memperjelas status pengelolaan dan penguasaan tanaman kemiri dan juga untuk menegakkan nilai alempureng (kejujuran) serta nilai siri (harga diri) dalam diri masyarakat. Masyarakat percaya apabila mencuri buah kemiri yang jatuh pada lahan yang telah dipasangi hompong maka pencuri tersebut akan tertimpa musibah seperti umur pendek atau terkena penyakit parah.

Setelah hompong dicabut oleh pemilik lahan yaitu setelah berakhirnya panen mabbali, maka diperbolehkan bagi masyarakat umum yang bukan pemilik lahan yang berminat untuk memungut dan memiliki buah 
Jurnal $\mathcal{P}$ enyuluhan, Maret 2012 Vol. 8 No. 1

kemiri tanpa harus meminta izin dari pemilik lahan atau biasa dikenal dengan makkalice.

\section{Maddepa}

Sebelum dijual dan/atau digunakan untuk kebutuhan sendiri, kemiri yang terkumpul dikupas/dipecah. Kegiatan ini dikenal dengan sebutan maddepa yang dilaksanakan oleh pemilik kemiri beserta anggota keluarga, atau mengikutser-takan masyarakat yang ada di sekitarnya dengan sistim bagi hasil apabila produksi kemirinya cukup banyak. Pengupasan/pemecahan (maddepa) dapat dilakukan langsung setelah pemungutan dari lapangan atau setelah disimpan pada tempat penyimpanan (abbibireng) yang dilakukan setelah melalui proses pengeringan. Alat yang digunakan untuk mengupas terlihat sangat sederhana, terdiri dari dua bagian yaitu alat untuk menghentakan biji kemiri yang terbuat dari rotan yang dianyam (paddepa), dan tempat atau landasan untuk menghentak biji kemiri yang terbuat dari batu sungai dengan permukaan datar.

\section{Mallolo}

Kemiri yang sudah tua dan menurun produktivitasnya oleh petani sekitar hutan, sebelum adanya kebijakan TGHK, dilakukan upaya peremajaan atau biasa disebut dengan mallolo. Kegiatan mallolo ini pada dasarnya pengulangan dari kegiatan mappamula dan makkoko. Pada kegiatan mallolo tanaman kemiri yang sudah tua dan menurun produktivitasnya ditebang dan kayu hasil tebangan tersebut kemudian dibakar. Kegiatan mallolo biasanya dilakukan pada akhir musim kemarau atau menjelang musim hujan agar kayu dan ranting serta dedaunan hasil penebangan cepat kering sehingga mudah dibakar. Proses penanaman biji kemiri sama dengan proses maddare, yaitu biji kemiri ditanam atau ditabur sebelum dilakukan pembakaran. Setelah melalui proses pembakaran areal tersebut kemudian dibiarkan. Kurang lebih selama satu bulan dan memasuki musim hujan akan tumbuh tunas/kecambah pohon kemiri, untuk kemudian oleh petani diadakan seleksi bibit/anakan atau tunas yang baik sambil mengatur jarak tanam kemiri.

\section{Dukungan Tokoh Masyarakat}

Tokoh masyarakat adalah orang atau sekelompok orang dalam suatu masyarakat yang memiliki kemampuan untuk mempengaruhi orang lain (Hanafie, 1986). Sarwono (2005) menyatakan untuk mengubah atau mendidik masyarakat seringkali diperlukan pengaruh dari tokoh-tokoh atau pemimpin masyarakat. Dukungan tokoh masyarakat dalam pengelolaan hutan kemiri berada dalam kategori rendah, yang ditunjukkan dengan skor rataan total 33,1. Secara statistik, terdapat perbedaan nyata antara dukungan tokoh masyarakat pada Kecamatan Cenrana dan Kecamatan Camba, walaupun pada kenyataannya skor rataan keduanya masih berada dalam kategori rendah, yaitu 36,4 untuk Kecamatan Cenrana dan 29,7 untuk Kecamatan Camba. Dukungan tokoh masyarakat di Kecamatan Cenrana terlihat lebih tinggi karena petani di Kecamatan Cenrana memiliki tingkat kebergantungan yang lebih tinggi terhadap hutan kemiri, termasuk tokoh masyarakatnya, dibandingkan dengan petani di dua kecamatan lainnya.

Rendahnya dukungan tokoh masyarakat dalam mendukung pengelolaan hutan, disebabkan tokoh masyarakat ikut merasakan dampak dari diberlakukannya TGHK. Tokoh masyarakat juga memiliki lahan kemiri yang akhirnya masuk menjadi kawasan hutan setelah diberlakukannya TGHK, sehingga mereka tidak lagi memiliki hak untuk mengelola hutan kemiri. Sama dengan petani lainnya, mereka hanya diberikan hak untuk mengakses hutan kemiri dalam bentuk pemungutan buah. Tokoh masyarakat merasakan bahwa prosedur penetapan kawasan hutan melalui TGHK bersifat topdown tanpa konsultasi publik atau melibatkan masyarakat lokal yang notabene petani sehingga berdampak pada dimasukkan tanaman kemiri yang selama ini mereka miliki ke dalam kawasan hutan. Prosedur penetapan kawasan hutan melalui TGHK, dengan demikian, tidak memberi peluang pada masyarakat untuk menyuarakan kebutuhan, kepentingan, dan aspirasinya.

Perubahan status hutan, menimbulkan dilema bagi tokoh masyarakat. Di satu sisi, 
Jurnal $\mathcal{P}$ enyuluhan, Maret 2012 Vol. 8 No. 1

tokoh masyarakat juga merasakan kekhawatiran akan keamanan akses ke lokasi hutan di mana terdapat tanaman kemiri miliknya karena kebijakan yang ada setelah diterapkannya TGHK tidak memberikan ruang yang cukup luas bagi masyarakat termasuk tokoh masyarakat untuk mengelola kawasan hutan kemiri. Di sisi lain, karena tokoh masyarakat adalah figur yang dihargai dan dituruti oleh masyarakat, terdapat kecenderungan adanya usaha kooptasi yang dilakukan oleh pemerintah terhadap tokoh masyarakat agar mau mengajak warganya untuk tidak melakukan kegiatan-kegiatan fisik pengelolaan tanaman kemiri yang berada dalam kawasan hutan, kecuali hanya memungut buah kemiri

\section{Dukungan Kelompok Tani}

Para petani biasanya menjadi bagian atau anggota dari kelompok tani. Kelompok mempunyai pengaruh terhadap perilaku anggota-anggotanya, yang meliputi pengaruh terhadap persepsi, pengaruh terhadap sikap, dan pengaruh terhadap tindakan individu (Santosa, 1992). Dukungan kelompok akan memicu dan memacu petani untuk mau terlibat dalam pengelolaan hutan, sebagaimana yang dinyatakan Beebe dan Masterson (1989) bahwa kelompok memegang peranan penting bagi perkembangan kepribadian dan perilaku seseorang.

Dukungan kelompok tani pada anggotanya terkait dengan pengelolaan hutan kemiri termasuk dalam kategori rendah, dengan rataan skor total 18,1. Perbedaan nyata dukungan kelompok tani terjadi di antara Kecamatan Cenrana dan Kecamatan Camba, namun demikian keduanya tetap termasuk dalam kategori rendah dimana skor rataan dukungan kelompok tani di Kecamatan Cenrana adalah 18,1 dan di Kecamatan Camba 24.

Secara formal berdasarkan Surat Keputusan Bupati Maros No. 111/KPTS/ 412.61/III/2007 tentang Pengukuhan Kelompok Tani-Nelayan Kabupaten Maros Tahun 2001 terdapat 181 kelompok tani yang tersebar di tiga kecamatan tersebut, dengan rincian di Kecamatan Cenrana terdapat 79 kelompok tani, 47 kelompok tani berada di
Kecamatan Camba dan 45 kelompok tani berada di Kecamatan Mallawa. Namun pada umumnya menurut petani kelompok tersebut dibentuk tidak berdasarkan inisiatif petani, melainkan bentukan atau inisiatif pemerintah dengan tujuan mendukung proyek-proyek pertanian, perkebunan, atau kehutanan yang diluncurkan pemerintah.

Berdasarkan hasil hasil wawancara diperoleh informasi bahwa terdapat beberapa petani yang lupa apakah mereka masih menjadi anggota kelompok atau tidak, bahkan ada di antara petani yang diwawancarai bertanya-tanya apakah kelompoknya masih ada atau sudah bubar, karena sudah lama tidak ada kegiatan kelompok. Disamping itu, sebagian petani yang menjadi anggota kelompok tidak memahami dengan pasti tujuan kelompoknya, karena keberadaan mereka dalam kelompok sekedar ikut-ikutan dengan harapan mendapat kemudahan memperoleh bantuan pemerintah, sehingga sebagian besar petani cenderung memahami bahwa tujuan terbentuknya kelompok adalah untuk mempermudah mereka mendapatkan bantuan dari pemerintah seperti pembagian bibit dan fasilitas lainnya jika ada proyek yang diluncurkan pemerintah, karena keberadaan kelompok merupakan salah satu prasyarat untuk memperoleh bantuan. Kondisi tersebut mengakibatkan kinerja kelompok tidak optimal. Petani yang menjadi anggota kelompok berharap adanya bimbingan dan pembinaan secara berkesinambungan baik dari pemerintah maupun swasta sehingga dapat terbentuk kelompok yang mandiri.

Kegiatan pengelolaan kemiri bukan usaha kelompok melainkan usaha rumah tangga atau indiuvidu, kondisi ini juga yang menjadi penyebab rendahnya dukungan kelompok, karena interaksi dalam bentuk kerjasama dan berbagi terfokus pada kegiatan budidaya pertanian dan perkebunan, sedangkan pada kegiatan kehutanan khususnya pengelolaan hutan kemiri hampir tidak pernah diperhatikan oleh anggota-angota kelompok petani. 
Jurnal $\mathcal{P}$ enyuluhan, Maret 2012 Vol. 8 No. 1

\section{Kondisi Tingkat Kemampuan Petani dalam Pengelolaan Hutan Kemiri}

Kegiatan pengelolaan hutan kemiri akan mencapai hasil yang baik, jika petani pengelola hutan tersebut memiliki kemampuan yang memadai. Kepemilikan kemampuan pada petani sekitar hutan kemiri meliputi kemampuan teknis, kemampuan manajerial dan kemampuan sosial diharapkan dapat menumbuhkan dan mendorong keberlanjutan proses pengelolaan hutan yang selama ini telah dilakukan petani dan meningkatkan keberlanjutan manfaat hutan yang dapat dinikmati petani.

Secara umum, tingkat kemampuan petani dalam mengelola hutan kemiri cenderung sedang, yang ditandai dengan aspek kemampuan teknis yang tergolong sedang dengan rataan skor 56,7 dan aspek kemampuan sosial yang juga tergolong sedang dengan rataan skor 67,9, kecuali aspek kemampuan manajerial yang masuk dalam kategori rendah dengan rataan skor 46,3 (Tabel 2).

\section{Kemampuan Teknis}

Kemampuan teknis responden, pada umumnya, berada dalam kategori sedang (rataan skor total 56,7). Perbedaan kemampuan teknis terjadi antara responden Kecamatan Camba dan Kecamatan Mallawa. Walaupun kemampuan teknis di tiga kecamatan tersebut berada dalam kategori sedang, namun bila dilihat berdasarkan urutan rataan skor maka kemampuan teknis tertinggi dimiliki oleh responden di Kecamatan Camba (rataan skor 58,7), diikuti oleh responden di Kecamatan Cenrana (rataan skor 57,9), dan yang terakhir adalah responden di Kecamatan Mallawa (rataan skor 55,1).

Kemampuan teknis ditinjau dari aspek kognitif termasuk dalam kategori sedang, ditandai dengan rataan skor total 78,8, aspek afektif berada dalam kategori sedang (rataan skor total 64,6). Sedangkan, aspek psikomotor berada dalam kategori rendah dengan rataa skor total 42,2 (Tabel 3 ).

Tabel 2. Sebaran rataan skor tingkat kemampuan petani sekitar hutan dalam pengelolaan hutan kemiri

\begin{tabular}{lcccc}
\hline $\begin{array}{c}\text { Tingkat Kemampuan } \\
\text { Petani dalam Mengelola }\end{array} \quad \begin{array}{c}\text { Kecamatan } \\
\text { Hutan Kemiri }\end{array}$ & $\%$ & $\begin{array}{c}\text { Kecamatan } \\
\text { Camba }\end{array}$ & $\begin{array}{c}\text { Kecamatan } \\
\text { Mallawa }\end{array}$ & Total \\
\cline { 2 - 5 } Kemampuan Teknis & & $\%$ & $\%$ & $\%$ \\
$\quad$ Rendah & 25,9 & 16 & 21 & 21,1 \\
Sedang & 74,1 & 84 & 79 & 78,9 \\
Tinggi & 0 & 0 & 0 & 0 \\
Rataaan Skor & 57,9 & $58,7^{(\mathrm{a})}$ & $55,1^{(\mathrm{a})}$ & 56,7 \\
\hline Kemampuan manajerial & & & & \\
$\quad$ Rendah & 44,4 & 58 & 89 & 69,6 \\
Sedang & 55,6 & 42 & 11 & 0 \\
$\quad$ Tinggi & 0 & 0 & 0 & 46,3 \\
Rataaan Skor & $53,4^{(\mathrm{a})(\mathrm{b})}$ & $49,1^{(\mathrm{a})(\mathrm{c})}$ & $41,2^{(\mathrm{b})(\mathrm{c})}$ & 5,9 \\
\hline Kemampuan sosial & & & & 73 \\
Rendah & 11,1 & 8 & 2 & 21,1 \\
Sedang & 55,6 & 76 & 81 & 67,9 \\
Tinggi & 33,3 & 16 & 17 & 68,5 \\
Rataaan Skor & 67,2 & 67,6 & & \\
\hline
\end{tabular}

Sumber: Analisis Data Primer, 2010

Keterangan: $\sum$ Cenrana $=54 ; \sum$ Camba $=50 ; \sum$ Mallawa $=100$

(a), (b), (c); hasil uji beda dengan ANAVA pada $\alpha=5 \%$

Kategori; Rendah $=$ skor $0-50$, Sedang $=$ skor $51-75$, Tinggi $=$ skor $76-100$ 
Tabel 3. Aspek-Aspek Kemampuan Teknis

\begin{tabular}{lcccc}
\hline \multirow{2}{*}{$\begin{array}{r}\text { Aspek Kemampuan } \\
\text { Teknis }\end{array}$} & $\begin{array}{c}\text { Kec. } \\
\text { Cenrana }\end{array}$ & $\begin{array}{c}\text { Kec } \\
\text { Camba }\end{array}$ & $\begin{array}{c}\text { Kec. } \\
\text { Mallawa }\end{array}$ & Total \\
\hline Aspek Kognitif & 70,9 & 80,9 & 82 & 78,8 \\
Aspek Afektif & 74,2 & 65,3 & 59,1 & 64,6 \\
Aspek Psikomotor & 37,8 & 45,2 & 43 & 42,2 \\
\hline
\end{tabular}

Sumber: Analisis Data Primer, 2010

Keterangan: $\sum$ Cenrana $=54 ; \sum$ Camba $=50$;

$\sum$ Mallawa $=100$

Kategori; Rendah = skor $0-50$,

Sedang $=$ skor $51-75$, Tinggi $=$ skor $76-100$

Temuan ini menunjukkan bahwa petani memiliki pemahaman dan keyakinan yang cukup baik tentang teknis pengelolaan hutan kemiri secara lestari meliputi teknik budidaya tanaman kemiri, identifikasi hama/penyakit tanaman kemiri, pencegahan dan pemberantasan hama dan penyakit, serta perlindungan hutan. Budidaya hutan rakyat dalam bentuk kebun kemiri, sebagai aktualisasi kemampuan teknis, pada dasarnya telah dikuasai oleh para petani sekitar hutan kemiri Kabupaten Maros, walaupun dalam pengertian apa adanya. Artinya mulai dari penyediaan biji, bibit, penanaman, pemeliharaan sampai siap untuk dijual, semuanya dilakukan secara tradisional berdasarkan kebiasaan dan pengetahuan yang diperoleh secara turun temurun.

Rendahnya aspek psikomotor bukan disebabkan oleh tidak terampilnya petani dalam mengelola tanaman kemiri, namun lebih disebabkan pada saat ini terbatasnya akses ke lahan kemiri yang berada dalam kawasan hutan, sehingga petani tidak lagi secara fisik melakukan pengelolaan tanaman kemiri. Padahal pada kenyataannya secara historis terbentuknya hutan kemiri yang ada pada saat ini merupakan hasil dari budidaya tanaman kemiri yang telah dilakukan oleh petani sekitar hutan secara turun temurun. Kenyataan tersebut merupakan bukti dari aktualisasi kemampuan teknis yang dimiliki petani, dengan demikian sejatinya petani sekitar hutan memiliki kemampuan teknis, dengan seluruh dimensinya yaitu aspek kognitif, afektif dan psikomotorik, yang memadai dalam mengelola hutan kemiri.
Kemampuan teknis yang dimiliki petani sekitar hutan kemiri Kabupaten Maros dalam mengelola hutan kemiri diperoleh melalui proses alih pengetahuan melalui pendidikan informal. Pendidikan informal pada umumnya diperoleh atau diturunkan dari orang tua dan sanak keluarga, terkadang juga dari tetangga, pertemanan, dan kelompok kecil informal sebagai pengayaan atau perbaikan dari pengalaman mengelola hutan kemiri secara bertahun-tahun. Orang tua merupakan sumber utama pembentukan kemampuan teknis dalam pengelolaan hutan kemiri. Responden yang berusia > 50 tahun mengatakan bahwa dulu ketika mereka berusia sekitar usia 10-11 tahun oleh orang tuanya sudah dianggap mampu untuk diikutkan ke kebun untuk belajar mencangkul, menebang pohon, menanam kemiri dan memungut buah kemiri. Hal ini sejalan dengan pendapat Sumardjo (2010) bahwa pendidikan, termasuk pendidikan informal, merupakan salah satu pilar utama bagi pengembangan kemandirian masyarakat. Kemandirian merupakan suatu prasyarat bagi masyarakat untuk berdaya dalam mengelola sumberdaya, termasuk sumberdaya hutan, dan beradaptasi terhadap berbagai perubahan lingkungan.

\section{Kemampuan Manajerial}

Selain sebagai juru tani, Mosher (1978) mengemukakan petani juga merupakan manajer atau pengelola dari usahatani yang dilakukannya. Kemampuan manajerial responden termasuk dalam kategori rendah, dengan rataan skor total 46,3 (Tabel 4). Terdapat perbedaan nyata kemampuan manajerial dari responden di antara tiga kecamatan tersebut. Dilihat dari rataan skor masingmasing kecamatan kemampuan manajerial responden Kecamatan Cenrana menempati posisi tertinggi dengan kategori sedang (rataan skor 53,4), diikuti oleh Kecamatan Camba dengan kategori rendah (rataan skor 49,1), dan Kecamatan Mallawa dengan kategori rendah (rataan skor 41,2).

Aspek kognitif dan aspek afektif dari kemampuan manajerial pengelolaan hutan kemiri berada dalam kategori sedang dengan rataan skor total 59,5 untuk aspek kognitif dan 
Jurnal $\mathcal{P}$ enyuluhan, Maret 2012 Vol. 8 No. 1

71,3 untuk aspek afektif, sedangkan aspek psikomotor berada dalam kategori rendah (rataan skor total 30,1). Hal tersebut menunjukkan bahwa responden tahu dan yakin pentingnya perencanaan, pengaturan, menggerakkan tenaga kerja, serta mengawasi dan menilai kegiatan usahatani kemiri dalam pengelolaan hutan kemiri secara lestari, namun secara faktual tidak serta merta dikikuti oleh tindakan aplikatif atau keterampilan, sehingga dapat dikatakan bahwa dalam konteks manajerial petani tahu, mau tetapi tidak mampu.

Tabel 4. Aspek-Aspek Kemampuan Manajerial

Sumber: Analisis Data Primer, 2010

\begin{tabular}{lcccc}
\cline { 3 - 5 } \begin{tabular}{c} 
Aspek Kemampuan \\
\cline { 2 - 5 } Manajerial
\end{tabular} & $\begin{array}{c}\text { Kec. } \\
\text { Cenrana }\end{array}$ & $\begin{array}{c}\text { Kec. } \\
\text { Camba }\end{array}$ & $\begin{array}{c}\text { Kec. } \\
\text { Mallawa }\end{array}$ & Total \\
\hline Aspek Kognitif & 64,81 & 63,00 & 54,80 & 59,46 \\
Aspek Afektif & 70,83 & 71,33 & 71,50 & 71,28 \\
Aspek Psikomotor & 41,48 & 34,13 & 21,96 & 30,11 \\
\hline Keterangan: $\sum$ Cenrana $=54 ; \sum$ Camba $=50 ;$ \\
\multicolumn{5}{c}{ Kategori; Rendah = skor 0-50, } \\
Sedang = skor 51-75, Tinggi = skor 76-100
\end{tabular}

Berdasarkan aspek psikomotor dari kemampuan manajerial pengelolaan hutan kemiri terdapat kecenderungan petani lebih suka melakukan budidaya tanaman kemiri hanya berdasarkan tradisi turun temurun atau apa adanya, belum dikelola secara profesional atau berdasarkan manajemen modern. Responden tidak melakukan secara tertulis perencanaan usahatani kemiri yang dikelolanya, pengaturan, pengawasan dan penilaian dilakukan seadanya hanya berdasarkan kebiasaan dalam arti tidak teroganisir dan sistematis, begitupula dengan menggerakkan tenaga kerja hanya berdasarkan kedekatan hubungan darah atau kekeluargaan.

\section{Kemampuan Sosial}

Secara umum kemampuan sosial responden berada dalam kategori sedang (rataan skor total 67,9). Kemampuan sosial responden di ketiga kecamatan, secara statistik, relatif sama Walaupun kemampuan teknis di tiga kecamatan tersebut relatif sama (dalam kategori sedang), namun bila dilihat berdasarkan urutan besarnya rataan skor terdapat ke- cenderungan responden dari Kecamatan Mallawa memliki kemampuan sosial yang lebih tinggi (rataan skor 68,5), diikuti dengan Kecamatan Camba (rataan skor 67,6), dan Kecamatan Cenrana rataan skor 67,2.

Ketiga aspek dari kemampuan sosial berada dalam kategori sedang, yang ditunjukkan dengan rataan skor total dari masing-masing aspek tersebut yaitu: rataan skor total 66,6 untuk aspek kognitif, 74,2 untuk aspek afektif, dan 63,8 untuk aspek psikomotor (tabel 5). Hal tersebut menunjukkan bahwa petani memiliki pemahaman, keyakinan, dan keterampilan yang memadai untuk berkomunikasi, bekerjasama, melakukan negosiasi, mengantisipasi dan meminimalisir timbulnya konflik ketika berhubungan dengan orang lain dalam kegiatan pengelolaan hutan kemiri. Artinya, dapat dikatakan bahwa secara memadai petani tahu, mau dan mampu menjalin hubungan dan interaksi sosial yang dinamis dengan pihak lain.

Tabel 5.Aspek-Aspek Kemampuan Sosial

\begin{tabular}{lcccc}
\hline \multirow{2}{*}{$\begin{array}{c}\text { Aspek Kemampuan } \\
\text { Sosial }\end{array}$} & \multicolumn{4}{c}{ Rataan Skor } \\
\cline { 2 - 5 } & $\begin{array}{c}\text { Kec. } \\
\text { Cenrana }\end{array}$ & $\begin{array}{c}\text { Kec. } \\
\text { Camba }\end{array}$ & $\begin{array}{c}\text { Kec. } \\
\text { Mallawa }\end{array}$ & Total \\
\hline Aspek Kognitif & 67,9 & 69,7 & 64,3 & 66,6 \\
Aspek Afektif & 75,8 & 74,2 & 73,3 & 74,2 \\
Aspek Psikomotor & 60,9 & 62,6 & 65,9 & 63,8 \\
\hline
\end{tabular}

Sumber: Analisis Data Primer, 2010

Keterangan: $\sum$ Cenrana $=54 ; \sum$ Camba $=50$;

$\sum$ Mallawa $=100$

Kategori; Rendah = skor 0-50,

Sedang $=$ skor $51-75$, Tinggi $=$ skor $76-100$

Kemampuan sosial yang dimiliki petani kawasan hutan kemiri terbentuk melalui proses belajar sosial yang bersifat informal yang berlangsung dalam ruang interaksi dengan lingkungan sosialnya dan telah berjalan secara turun temurun. Kemampuan sosial petani, dengan demikian, merupakan internalisasi strategi adaptif petani untuk mengatasi dan mengantisipasi berbagai problema sosial yang muncul dan/atau dihadapi didalam lingkungan sosialnya. Dapat dikatakan bahwa terbentuknya perilaku petani termasuk didalamnya kemampuan sosial petani bersumber dari modal sosial dan/atau kultur masyarakat. Budaya menetapkan norma-norma yang harus dipatuhi oleh masyarakat. Norma-norma ini pada 
akhirnya mendorong terbentuknya kemampuan sosial dalam rangka menjaga harmonisasi hubungan kemasyarakatan. Kemampuan sosial yang dimiliki petani sekitar hutan kawasa kemiri, dengan demikian, terbentuk dan dipengaruhi oleh nilai-nilai luhur dalam budaya, baik diturunkan dari orang-orang tua melalui paseng (pesan) atau dari dalam catatan lontara.

\section{Kontribusi Lingkungan Sosial Budaya terhadap Kemampuan Petani Sekitar Hutan dalam Pengelolaan Hutan Kemiri Rakyat}

Berdasarkan hasil analisa SEM dengan LISREL 8.70 diperoleh hasil bahwa lingkungan sosial budaya memberikan pengaruh positif pada tingkat kemampuan petani dalam mengelola hutan kemiri. Aspek-aspek lingkungan sosial budaya yang memberikan pengaruh pada tingkat kemampuan petani adalah: (1) dukungan kearifan lokal; dan (b) dukungan tokoh masyarakat (Gambar 1).

Hal ini berarti bahwa semakin tinggi dukungan lingkungan sosial budaya maka akan semakin meningkatkan kemampuan petani sekitar hutan dalam mengelola hutan kemiri. Temuan ini sejalan dengan pendapat Delgado dalam Rakhmat (2002) yang menyatakan bahwa respons otak dan perilaku individu dipengaruhi oleh setting atau suasana yang melingkupi individu tersebut, begitu pula dengan Santosa (2004) menyimpulkan bahwa lingkungan sosial memiliki pengaruh besar terhadap perilaku adaptif petani tepian hutan. Utama (2010) mengemukakan bahwa dukungan lingkungan merupakan kekuatan dan kualitas dari luar diri petani hutan yang secara langsung mempengaruhi tingkat keberdayaan petani sekitar hutan dalam mengelola hutan.

\section{Dukungan kearifan lokal}

Dukungan lingkungan sosial budaya yang paling berpotensi mempengaruhi tingkat kemampuan petani sekitar hutan dalam mengelola hutan kemiri adalah dukungan kearifan lokal. Kearifan lokal, dengan demikian, merupakan kekuatan potensial yang berpengaruh penting kemampuan petani dalam mengelola hutan kemiri secara lestari. Kearifan lokal dalam pengelolaan hutan kemiri merupakan pengetahuan yang eksplisit yang muncul dari periode panjang yang berevolusi bersamasama masyarakat dan lingkungannya dalam sistem lokal yang sudah dialami bersamasama. Kearifan lokal ini telah melembaga dan telah menciptakan hubungan yang serasi antara petani dengan hutan kemiri, yang kemudian mendasari praktek pengelolaan hutan kemiri dan telah menciptakan hubungan yang harmonis di antara petani dalam pengelolaan hutan kemiri.

Praktek pengelolaan hutan kemiri yang dilandasi oleh pengetahuan dan kearifan lokal yang selama ini dilakukan meliputi mappamula (kegiatan persiapan lahan), pengadaan bibit, maddare (penanaman), pemeliharaan tanaman, makkampiri (pemungutan hasil) dan pemasaran hasil, kesemuanya secara langsung mempengaruhi terbentuknya kemampuan petani sekitar hutan kemiri. Nilainilai kearifan yang dianut petani sekitar hutan kemiri yang mendukung terciptanya praktek pengelolaan hutan kemiri yang baik, antara lain reso (usaha), anennungeng (ketekunan), sipatuwo (saling menghidupi) dan sipatok-

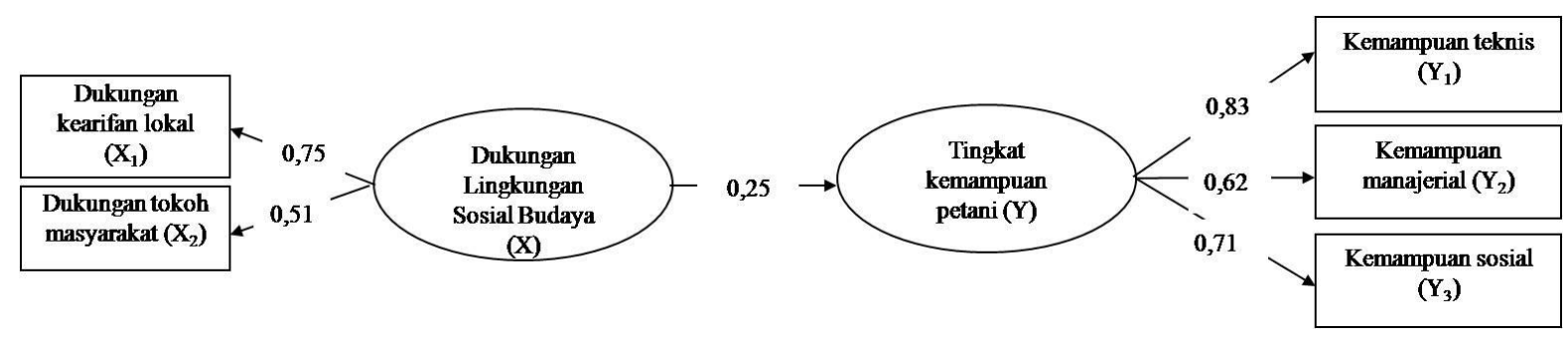

Chi-Square $=182,06, d f=154, p$-value=0,06077, $R M S E A=, 0.030, C F I=0,9782, \quad G F I=0,9348$

Gambar 1. Model struktural pengaruh dukungan lingkungan sosial budaya terhadap kemampuan petani dalam pengelolaan hutan kemiri 
Jurnal $\mathcal{P}$ enyuluhan, Maret 2012 Vol. 8 No. 1

kong (saling membangun), serta adanya $p a$ seng (pesan) seperti manusia tercipta dari tanah maka berdosa manusia tersebut jika tidak mau mengolah tanahnya dengan baik (iya rupa tauwe ipancajiwi pole ritanae, namadosai narekko de' nakkarawa tana), bertani dan mengolah tanah adalah pekerjaan terhormat dan banyak mendapat pahala (naiyya jamang pallaorumae sibawa pakkarawa tanae, iyanaritu jamang mallebi, namaega, appalanna).

Fakta penelitian menunjukkan bahwa dukungan kearifan lokal pengelolaan hutan kemiri berada dalam kategori sedang. Kearifan lokal dalam mengelola hutan kemiri, dengan demikian, perlu untuk dipertahankan eksisitensinya bahkan ditingkatkan fungsinya karena memberikan dampak positip terhadap tingkat kemampuan petani sekitar hutan dalam mengelola hutan kemir secara lestari.

Pada saat ini, telah terjadi pergeseran atau memudarnya nilai-nilai kearifan lokal sebagai akibat dari perkembangan kehidupan sosial masyarakat dan terjadinya proses kawin mawin dengan pihak luar atau orang yang tidak memiliki hubungan emosional dengan nilai-nilai tersebut, misalnya pada saat ini tidak semua petani sekitar hutan meyakini kesakralan atau kekuatan supranatural hompong. Kegiatan mabbali dan makkalice juga sudah mulai hilang, karena rendahnya produktivitas kemiri. Maddepa yang sebelumnya merupakan refleksi ciri kegotongroyongan dimana sistim bagi hasil tidak terikat oleh aturan besarnya jasa, pada saat ini karena tuntutan kebutuhan hidup cenderung bergeser kepada sistim pengupahan berdasarkan besarnya kontribusi jasa.

Terbatasnya akses petani ke dalam hutan juga turut memberikan kontribusi memudarnya kearifan lokal dalam praktek pengelolaan hutan, antara lain nilai-nilai yang mengatur petani untuk melakukan peremajaan tanaman kemiri (mallolo), yang pada hakikatnya merupakan operasionalisasi fungsi rehabilitasi dan konservasi, sudah tidak lagi dilaksanakan.

\section{Dukungan tokoh masyarakat}

Dukungan lingkungan sosial budaya berikutnya yang berpotensi mempengaruhi tingkat kemampuan petani dalam mengelola hutan kemiri adalah dukungan tokoh masyarakat. Tokoh masyarakat adalah satu atau beberapa orang yang oleh masyarakat dianggap memiliki nilai lebih dibandingkan dengan kebanyakan orang di dalam masyarakat tersebut. Tokoh masyarakat sekitar hutan kemiri, dengan demikian, dapat memainkan peranan penting dalam memotivasi masyarakat atau petani sekitar hutan untuk melestarikan hutan. Temuan ini sejalan dengan pendapat Rogers dan Shoemaker yang disarikan oleh Hanafie (1986) bahwa tokoh masyarakat memainkan peranan penting dalam mempengaruhi perilaku orang lain. Tokoh masyarakat memiliki kemampuan mempengaruhi orang lain untuk bertindak dalam cara-cara tertentu. Demikian pula, penelitian Waskito (2000) mengungkapkan bahwa tokoh masyarakat di Desa Gunungsari Kabupaten Boyolali telah berhasil mengajak masyarakat untuk belajar bersama dan membangun hutan rakyat.

Fakta penelitian menunjukkan dukungan tokoh masyarakat terhadap petani dalam pengelolaan hutan kemiri berada dalam kategori rendah. Pada saat ini tokoh masyarakat berkurang antusiasnya untuk mengajak warganya mengelola hutan kemiri. Rendahnya dukungan tokoh masyarakat karena pada hakekatnya mereka adalah bagian dari masyarakat petani sekitar hutan sehingga merasakan hal yang sama dengan petani lainnya, yaitu tidak memiliki akses ke dalam hutan untuk mengelola hutan kemiri. Tokoh masyarakat, sama dengan petani lainnya, hanya diberikan hak untuk mengakses hutan kemiri dalam bentuk pemungutan buah, sehingga perhatian mereka terhadap upaya pengelolaan hutan kemiri juga rendah. Rendahnya dukungan tokoh masyarakat didasari juga oleh adanya pengalaman pada tahun 1980-an ketika harga kemiri sedang tinggi, di mana seorang tokoh masyarakat pada salah satu desa sekitar hutan kemiri mengajak masyarakatnya untuk melakukan malollo (peremajaan) yang pada akhirnya menyeret tokoh masyarakat tersebut dan beberapa warga harus berurusan dengan hukum.

\section{Kesimpulan}

Kemampuan petani dalam pengelolaan hutan kemiri, tergolong sedang, yang diciri- 
kan oleh kemampuan teknis dan kemampuan sosial yang tergolong sedang, kecuali kemampuan manajerial yang tergolong rendah. Kemampuan tersebut diperoleh melalui pendidikan informal yaitu proses alih pengetahuan yang diperoleh atau diturunkan dari orang tua dan sanak keluarga,

Kondisi lingkungan sosial budaya petani sekitar hutan kemiri berada dalam kategori rendah, terlihat dari rendahnya aspek dukungan tokoh masyarakat maupun dukungan kelompok tani, kecuali aspek dukungan kearifan lokal yang tergolong sedang.

Aspek lingkungan sosial budaya yang memberikan pengaruh nyata positip terhadap tingkat kemampuan petani dalam mengelola hutan kemiri adalah (1) dukungan kearifan lokal, dan (2) dukungan tokoh masyarakat.

\section{Daftar Pustaka}

Beebe, S.A, Masterson JT. 1989. Communicating in Small Groups: Principles and Practices. Glenview, Illinois: Harper Collins Publishers.

Hadjar, I. 1996. Dasar-Dasar Metodologi Penelitian Kwantitatif dalam Pendidikan. Jakarta: RajaGrafindo Persada.

Hanafi, A. 1986. Memasyarakatkan Ide-Ide Baru. Surabaya: Usaha Nasional.

Klausmeier, H.J. dan Goodwin, W. 1975. Learning and Human Abilities: Educational Psychology. New York: Harper \& Row Publisher.

Kountur, R. 2006. Metode Penelitian: Untuk Penulisan Skripsi dan Tesis. Jakarta: Penerbit PPM.

Mitchell, B., Setiawan, B. dan Rahmi, D.H. 2007. Pengelolaan Sumberdaya dan Lingkungan. Yogyakarta: Gajah Mada University Press.

Mosher, A.T. 1978. Menggerakkan dan Membangun Pertanian. Jakarta: Yasaguna.

Ndraha, T. 1999. Pengantar Teori Pengembangan Sumberdaya Manusia. Jakarta: Rineka Cipta.

Rakhmat, J. 2002. Psikologi Komunikasi. Bandung: Remaja Rosdakarya.

Santosa, S. 1992. Dinamika Kelompok. Jakarta: Bumi Aksara.
Santosa, I. 2004. Pemberdayaan Petani Tepian Hutan Melalui Pembaharuan Perilaku Adaptif [disertasi]. Bogor: Institut Pertanian Bogor.

Sarwono, S.W. 2002. Psikologi Sosial: Individu dan Teosi-Teosi Psikologi Sosial. Jakarta: Balai Pustaka.

Seng, T.O., Parsons, R.D., Hinson, S.L. dan Brown, D.S. 2001. Educational Psychology. A Practitioner-Research Approach (An Asian Edition). Singapore: Seng Lee Press.

Sevilla, C.G., Ochave, J.A., Punsalan, T.G., Regala, B.P, dan Uriarte, G.G. 1993. Pengantar Metode Penelitian. Alimuddin Tuwu, penerjemah. Jakarta: UI Press. Terjemahan dari: An Introduction to Research Methods.

Soemarwoto, O. 1999. Analisis Mengenai Dampak Lingkungan. Yogyakarta: Gajah Mada University Press.

Spencer, L.M. dan Spencer, S.M. 1993. Competence at Work. New York: John Wiley \& Sons Inc.

Sumardjo. 2010. Penyuluhan Мепијu Pengembangan Kapital Manusia dan Kapital Sosial dalam Mewujudkan Kesejahteraan Rakyat. Orasi Ilmiah Guru Besar Tetap Fakultas Ekologi Manusia Intitut Pertanian Bogor, 18 September 2010. Bogor: Intitut Pertanian Bogor.

Utama, S. 2010. Pemberdayaan Masyarakat Sekitar Hutan Melalui Pendekatan Kelompok (Kasus Pengelolaan Hutan Bersama Masyarakat Pada Areal Hutan Produksi Perum Perhutani Unit I Provinsi Jawa Tengah) [disertasi]. Bogor: Institut Pertanian Bogor.

Walgito, B. 2003. Psikologi Sosial: Suatu Pengantar. Yogyakarta: Andi.

Waskito, B. 2000. Hutan Rakyat: Studi Kemungkinan Pengembangan (Kasus di Desa Gunngsari, Kabupaten Boyolali, Jawa Tengah). Di Dalam Hutan Rakyat Di Jawa: Perannya dalam Perekonomian Desa. Suhardjito, penyunting. Bogor: P3KM-Fahutan IPB. 